\title{
Clinical and economic aspects of the use of rituximab in non- Hodgkin's lymphoma
}

\section{Camila Bezerra Melo Figueirêdo 1 , Joelma Rodrigues de Souza ${ }^{2}$, Daniel Handerson Galindo Soares ${ }^{3}$, Caio Cesar de Andrade Rodrigues Silva ${ }^{1}$, Virginia Maria Barros de Lorena ${ }^{4, *}$}

\author{
${ }^{1}$ Laboratory of Drug's Technology, Department of Pharmaceutical Sciences, Federal University of Pernambuco, Recife, \\ Brazil, ' ${ }^{2}$ Department of Physiology and Pathology, Center of Health Sciences, Federal University of Paraiba, João Pessoa, PB, \\ Brazil, ${ }^{3}$ Secretariat of Public Health of Sertânia, Sertânia, PE, Brazil, ${ }^{4}$ Department of Immunology, Center of Research Aggeu \\ Magalhães, Oswaldo Cruz Foundation, Recife, PE, Brazil
}

\begin{abstract}
Non-Hodgkin's lymphoma (NHL) consists of a group of neoplasias involving mainly B cells and represents $90 \%$ of all lymphomas. The current available therapy is based on chemotherapy associated with the monoclonal antibody rituximab (Mab Thera ${ }^{\circledR}$ ), which targets the CD20 protein, present in over $80 \%$ of NHL mature B cells. Recent clinical reports show a preference for combining the benefits of immunotherapy and adjuvant chemotherapy, thus generating safe and effective alternative treatments. The current review aimed at evaluating various aspects related to the use of rituximab for NHL, highlighting the possible inhibitory mechanisms of cell proliferation, the achieved clinical results, and the expected clinical and economic outcomes of treatments. The results from clinical tests indicate the need for a better understanding of the critical mechanisms of action of this antibody, which may maximize its therapeutic efficacy. This therapy not only represents a viable option to treat most types of NHLs, especially when associated with conventional chemotherapy, but also offers cost-utility and cost-effectiveness advantages.
\end{abstract}

Uniterms: Non-Hodgkin's lymphoma. Antineoplastic combined chemotherapy/protocols. Adjuvant chemotherapy. Rituximab/application/Non-Hodgkin's lymphoma.

O Linfoma não-Hodgkin (LNH) consiste em um grupo de neoplasias envolvendo, principalmente, as células B e representa $90 \%$ de todos os linfomas. A terapia atual disponível é baseada em quimioterapia associada ao anticorpo monoclonal rituximabe (Mab Thera ${ }^{\circledR}$ ), que tem como alvo a proteína CD20, presente em mais de $80 \%$ das células B maduras do LNH. Recentes relatórios clínicos mostram preferência para combinar os benefícios da quimioterapia adjuvante e imunoterapia, gerando alternativas de tratamentos seguro e eficaz. O trabalho de revisão teve por objetivo avaliar vários aspectos relacionados à aplicação do rituximabe no LNH, destacando os possíveis mecanismos inibitórios da proliferação celular, os resultados clínicos obtidos e as implicações clínicas e econômicas esperadas para o tratamento. Os resultados de testes clínicos indicam a necessidade de uma melhor compreensão dos mecanismos críticos de ação deste anticorpo, que poderão maximizar a sua eficácia terapêutica. Essa terapia não representa apenas uma opção viável para o tratamento da maioria dos tipos de LNH, principalmente quando associado à quimioterapia convencional, mas, também, oferece vantagens em termos de custoutilidade e custo-efetividade.

Unitermos: Linfoma não-Hodgkin. Quimioterapia combinada antineoplásica/protocolos. Quimioterapia adjuvante. Ribuximabe/aplicação/Linfoma não-Hodgkin.

\footnotetext{
*Correspondence: V. M. B. Lorena. Departamento de Imunologia, Centro de Pesquisas Aggeu Magalhães, Fundação Oswaldo Cruz, Universidade Federal de Pernambuco. Av. Moraes Rego, s/n, Caixa Postal 7472, 50670-420 - Recife - PE, Brasil. E-mail: lorena@cpqam.fiocruz.br
} 


\section{INTRODUCTION}

Lymphomas comprise a diverse group of malignant neoplasias caused by clonal proliferation of B or T lymphocytes in lymph nodes. In general, lymphomas are divided into two morphologically distinct groups, namely Hodgkin's Lymphoma (HL) and Non-Hodgkin's Lymphoma (NHL). In particular, NHL derives from subpopulations of white blood cells, predominantly B lymphocytes (around 85\%), and, generally, affects the central nervous system, bone marrow, peripheral lymph nodes, and a region near the tonsils (SBC, 2013).

NHL prevalence rates are increasing worldwide and are slightly higher in men, especially Caucasians. The average age of cases is 65 , with the highest incidence found in people between 8085 (INCA, 2013). In Brazil, an estimated 9,100 new cases of the disease were reported in 2009, of which 4,900 were men and 4,200 women. Moreover, the number of deaths due to NHL in Brazil reached 3,568 (INCA, 2012). In the United States, the estimated number of new NHL cases reached 66,000 in 2011 (National Cancer Institute, U.S., 2012). Moreover, some studies include NHL as the fifth cause of death by cancer and the main type of deadly tumor in people aged 20 to 40 (Jazirehi, Bonavida, 2005).

Currently, over 20 types of NHL are known (INCA, 2013), with clinical aspects varying according to histological type, indolent (low-grade), intermediate, or aggressive (high-grade) (SBC, 2013). The aggressive forms present a high level of cell proliferation, large cells and localized lymphadenopathy, and may lead to death if not treated. This group includes the diffuse large B cell lymphoma (DLBCL), representing 58\% of the cases (Araújo et al., 2008).

The indolent lymphoma corresponds to $40 \%$ of reported cases and, although initially responsive to several therapies, they are characterized by a low level of cell proliferation, continuous and relapsing growth, low aggressiveness, and by being incurable. Cells are small and there is a formation of large masses of lymph nodes (INCA, 2012). Folicular lymphoma represents $70 \%$ of this group (Vinjamaram et al., 2011).

Distinct causes are suggested for NHL, including immune deficiency (e.g. Acquired Immune Deficiency Syndrome-AIDS), auto-immune disorders (e.g. Hashimoto's thyroiditis and Sjögren Syndrome), infectious agents (e.g. Human T-cell Lymphotropic Virus type I - HTLV1, Epstein-Barr Virus-EBV and Helicobacter pylori), and physical and chemical agents (e.g. insecticides, solvents, anticonvulsants, benzenes, paint thinner). However, the actual etiology of most cases remains undetermined (SBC, 2013).
The conventional treatment for NHL generally involves radiotherapy and antineoplastic chemotherapy. Nevertheless, these options have been shown to be ineffective in most cases, since less than $25 \%$ of patients are cured (SBC, 2013) and due to the fact that chemotherapy is highly toxic (Chanan-Khan, 2005). The development and application of monoclonal antibodies (MAbs) for diagnosis and treatment of tumors represented a great advance in the management of this group of diseases. Among the developed MAbs, Rituximab (Mab Thera ${ }^{\circledR}$ ) stands out, a chimeric MAb that targets the CD20 protein present in most part of B cells involved in NHL (Cheson, Leonard, 2008).

The major study that led to Rituximab's approval by the U.S. Food and Drug Administration (FDA) in 1997 showed significant activity of the drug in indolent B cell lymphomas, with a $50 \%$ response rate in relapsing and refractory disease. Furthermore, recent clinical results indicate its use against aggressive NHL when associated with conventional chemotherapies (Smith, 2003). Also for other types of NHL, the combination of rituximab with conventional chemotherapy resulted in significant progress in response rates, progression-free survival and overall survival (Kahl et al., 2010; Marcus, 2008).

Still, an improvement of rituximab-based therapies depends, in part, on a better understanding of the critical in vivo mechanisms of action, which remains unclear even with mechanisms such as cytotoxicity and apoptosis induction being suggested (Czuczman et al., 2008). Moreover, given the higher cost of this drug in comparison to conventional chemotherapies, a pharmacoeconomic analysis of treatments becomes necessary, as well as the analysis of the clinical results already achieved (Hernández-Rivera et al., 2008).

\section{METHODS}

The current review was performed through a systematic bibliographic search aimed at identifying the aspects relevant to the study. Medline (compiled from the National Library of Medicine), Bireme (International Database in Health Sciences), Lilacs (Latin-American and Caribbean Database in Health Sciences), Scielo Brasil and Pubmed Central ${ }^{\circledR}$ databases were used and several studies on the possible mechanisms of action of rituximab, clinical efficacy of rituximab against NHL and pharmacoeconomic analysis of the proposed therapies were selected. The terms used for the search included 'Rituximab', 'efficacy', 'CD20', 'mechanisms of action', 'non-Hodgkin's lymphoma' and 'pharmacoeconomics'. Over 40 articles were selected from these databases 
and additional information was obtained from websites containing relevant information on the subject.

\section{RESULTS AND DISCUSSION}

\section{Inhibitory mechanisms of cell proliferation}

The advances obtained by genetic engineering are responsible for the current therapy for NHL based on monoclonal antibodies that act against specific markers expressed on tumor cells (Van Der Kolk et al., 2002). Among the main MAbs for clinical use, rituximab stands out, being a chimeric antibody predominantly human (95\%), that targets the CD20 protein, expressed in over $80 \%$ of B cells of NHL and in normal B cells (Czuczman, 2002).

CD20 has been shown to be a suitable tumor marker, since it is found in mature normal and tumor B cells (Van Der Kolk et al., 2002); it is overexpressed in tumor B cells; it does not circulate free in plasma, which would inhibit antibody binding to lymphoma cells; it is membrane-stable; it remains attached to the cell surface after antibody binding and it is not internalized by the cells (Coiffier, 2002).

Some of the suggested inhibitory mechanisms of cell proliferation by rituximab are antibody-dependent cellmediated cytotoxicity (ADCC), complement-dependent cytotoxity (CDC), direct induction of apoptosis, inhibition of signal transduction (Cheson, Leonard, 2008) and finally sensitization of B cells to the cytotoxicity of chemotherapy drugs such as fludarabine, cisplatin, vinblastine and adriamycin (Jazirehi, Bonavida, 2005).

The CD20 antigen is composed of a transmembrane protein of 297 amino acids and its intracellular region is associated with tyrosine kinase. The involvement of this signaling molecule in several functions has been suggested, such as cell activation, proliferation and differentiation. It is believed that it also plays an important role in the regulation of calcium channel conductance and in stimulating apoptosis through the $\mathrm{Bcl}-2$ protein (Czuczman et al., 2008; Hernández-Rivera et al., 2008).

In fact, a few researchers suggest that CD20 may function as a large calcium channel. One study showed that when CD20 was introduced in cell lines by transfection, there was an increase in intracellular calcium in transfected cells. Taking this into consideration, monoclonal antibodies that act against CD20, such as Rituximab, induce the calcium influx which leads to the release of caspases and induction of apoptosis, causing the death of tumor cells (Bishop, 2012).

NHL is also characterized by chromosomal translocation of $\mathrm{Bcl}-2$ proto-oncogene, which occurs in over $80 \%$ of indolent NHL and results in the overexpression of the anti-apoptotic Bcl-2 protein (Czuczman, 2002). This protein may be involved in the lymphoma clinical evolution to the aggressive form, in the low survival rates of patients and in chemotherapy resistance. An increase in $\mathrm{Bcl}-2$ expression in NHL results in the stabilization of mitochondria membrane, which prevents the release of cytochrome $\mathrm{c}$, thus disrupting the apoptosis signaling cascade, responsible for the activation of caspases (Oliveira, Costa, Fonseca, 2006).

In order to prove this hypothesis, in vitro studies showed the involvement of CD20 with rituximab in decreasing Bcl-2 protein expression through IL-10 inhibition and inactivation of the signal transducer and activator of transcription 3(STAT3). This resulted in the sensitization of B cells to the cytotoxic agents, allowing the activity of anti-tumor drugs. Thus, the activity of rituximab against NHL was improved when Bcl-2 was overexpressed in patients (Jazirehi, Bonavida, 2005).

Analysis of circulating malignant B cells immediately after in vivo treatment with rituximab showed activation of caspases in these cells, which leads to the cleavage of several important proteins such as poly ADP-ribose polymerase. The apoptotic effect in malignant cells was observed before other potential mechanisms, suggesting that the direct apoptosis induced by rituximab may play a role in the depletion of circulating malignant $B$ cells, facilitating the downstream cytotoxic effects (Byrd et al., 2002).

The binding mechanisms of Rituximab to CD20 that will generate cytotoxicity are not totally known, but probably involve other mechanisms. ADCC involves the binding of the MAb Fc region to cell receptors of monocytes, natural killer (NK) cells and granulocytes. These effector immune cells cause the destruction of B cells bound to rituximab by phagocytosis or release of cytotoxic granules (Smith, 2003).

To demonstrate this mechanism, studies using transgenic animals that do not express receptors for antibody binding showed that events involving the $\mathrm{Fc}$ region affect the effectiveness of rituximab therapy. These events are related to ADCC modulation, which is linked to the presence of FcyRIII activation receptors and with the lack of FcyRIIB inhibitory receptors, present in myeloid cells. These findings also point to the importance of selecting and engineering therapeutic antibodies against tumors in order to maximize their interactions with FcyRIII and minimize the interactions with FcyRIIB, possibly potentiating their therapeutic capacities (Clynes et al., 2000).

An in vivo study showed that the absence or the low concentration (10 to $100 \mathrm{ng} / \mathrm{mL}$ ) of fucose in the 
oligosaccharide core of the MAb Fc region is related to ADCC potentiation in comparison to its fucosylated counterparts. This may be a promising approach for generating therapeutic antibodies with improved efficacy (Iida et al., 2009).

The association of an antibody to CD20 also initiates the complement cascade, resulting in the formation of the membrane attack complex (MAC), which will punch holes in the cell membrane and lead to cell lysis and death (Smith, 2003). Evidence for CDC was obtained from in vitro studies that showed rituximab activated the complement system to destroy a variety of lymphomas. However, the excitement with this discovery vanished when destruction of B cells induced by rituximab also occurred in transgenic mice deficient in complement factors $(\mathrm{C} 1 \mathrm{q}, \mathrm{C} 3, \mathrm{C} 4)$. Thus, the actual role of complement in rituximab activity remains to be elucidated (Uchida et al., 2004).

The involvement of memory $\mathrm{T}$ cells is another mechanism of action that has been under focus. The average response period in patients that responded to rituximab maintenance treatment was longer than that observed during the first treatment with this antibody. This fact led some investigators to suggest that induction of malignant $B$ cell death by rituximab generates apoptotic fragments (release of specific lymphoma antigens) that will be processed by antigen presenting cells (APCs, more specifically dendritic cells) and presented to T cells, which will turn into memory $T$ cells, responsible then for the long-lasting response of rituximab. The activation of this T-cell response by or the "vaccinal effect" of rituximab would be responsible for an anti-lymphoma immunity that persists much longer than the initial cytotoxic effect generated by the antibody itself. Nevertheless, these results remain unclear and further analyses on the effect of these immune mechanisms are necessary to determine in vivo responses (Selenko et al., 2002; Rafiq, Bergtold, Clynes, 2002).

As noted, therapy based on the anti-CD20 antibody involves several other effector immune components, such as monocytes, macrophages, neutrophils and NK cells. Thus, in the case of a high tumor burden, rituximab is infused to saturate all accessible binding sites for CD20, leading to a depletion of immune effector components and, consequently, limiting the complete effectiveness of this antibody. Considering that, the association of rituximab with conventional anti-tumor drugs may achieve better results against tumors (Taylor, Lindorfer, 2008).

Another important fact is that although rituximab is effective in treating B cell lymphomas, $50 \%$ of affected people presenting relapsing low-grade lymphoma do not respond to the initial therapy with this drug (Belo, Sotomayor, 2007). Moreover, $60 \%$ of the patients that respond to the initial treatment are not benefited by maintenance treatment using only this antibody, thus the application of radiotherapy and antineoplastic chemotherapy cycles becomes necessary. It has been suggested that resistance to treatment arises due to alterations in CD20 expression or signaling, which increases apoptosis threshold, modulates complement system activity and decreases cytotoxicity (Smith, 2003).

\section{Results on the clinical efficacy of Rituximab}

Chemotherapy drugs are usually used in combinations such as $\mathrm{CHOP}$ (cyclophosphamide, doxorubicin, vincristine and prednisone) and CVP (cyclophosphamide, vincristine and prednisone). These combinations are beneficial to treat progressive and bulky disease and increase the response rates in comparison to individual drugs. However, they do not improve the overall survival of patients (Horváth et al., 2009; Barr et al., 2009; Tobinai et al., 2009). Moreover, the use of these cocktails should be carefully evaluated in high-risk patients, such as those with cardiovascular and respiratory diseases, especially the elderly (over 60 years of age) (Pontes et al., 2012).

Rituximab was initially used in patients with relapsed follicular NHL, but later became first-line treatment (Foster, 2009). The main study that contributed to Rituximab approval by the FDA showed a significant activity against indolent B cell lymphomas, with a 50\% response rate against relapsing and refractory disease using a weekly dose of $375 \mathrm{mg} / \mathrm{m}^{2}$ for four weeks. Considering the pharmacokinetics of MAb, the mean half-life in the plasma varies from 10 to 14 days, thus allowing a $375 \mathrm{mg} / \mathrm{m}^{2}$ single dose per week administration schedule (Ritter et $a l ., 2008)$. So, due to its safety and efficacy, rituximab has emerged as a new standard for the treatment of follicular NHL, alone or in association with chemotherapy (Foster, 2009). Indeed, rituximab promotes better results when compared to chemotherapy alone or as a first or second line treatment. In combination with CVP or CHOP, Rituximab promotes an overall response rate of 81-97\% (Vose, 2006; Marcus, 2008, Foster, 2009). The use of rituximab alone, or in combination, for patients with relapsed or refractory disease, results in an overall response rate (ORR) of 5065\% (Strauss, 2006; Foster, 2009).

In the case of indolent lymphomas, an improvement of progression-free survival from 7 to 27 months was achieved (Marcus, 2007). However, better results are seen when rituximab is combined with antineoplastic chemotherapy (Belo, Sotomayor, 2007). 
A Phase II preliminary study in 40 patients, where 31 had not been previously treated for indolent NHL, 3 weekly cycles of CHOP were administered, with 2 doses of rituximab at the beginning and at the end of this schedule, besides an infusion before the $3 \mathrm{rd}$ and 5 th cycles. The overall response rate was $95 \%$ (38 out of 40 patients), where $22(55 \%)$ of them presented a complete response. The average time for disease progression was not achieved after 50 months of therapy and the response rate was $100 \%$ for patients that completed the treatment (Czuczman, 2002).

For the first-line treatment of follicular lymphoma, R-CHOP (rituximab combined with CHOP) compared to CHOP alone as the first-line treatment for follicular lymphoma, the overall response was 85.1 versus $72 \%$, and the complete response rates were $29.5 \%$ and $15.6 \%$, respectively. An increase in progression free survival from 22 to 33 months was also observed (Van Oers et al., 2006).

When R-CVP (rituximab combined with CVP) was compared to CVP alone as the first-line treatment in patients with low-grade lymphoma, the overall response and complete remission also indicated that the combined chemotherapy was more advantageous, corresponding to 41 and $81 \%$, versus 10 and $57 \%$, respectively (Marcus, 2007).

In addition, Chao et al. (2010) found a synergistic action between rituximab and the anti-CD47 antibody when eliminating $60 \%$ of NHL induced in mice with increased long-term survival. The mechanism of synergism involves the $\mathrm{Fc}$ receptor $(\mathrm{FcR})$-independent, enabling phagocytosis by anti-CD47 and FcR-dependent stimulating phagocytosis by rituximab.

Still with regard to other possible therapy combinations, Leahy and Turner (2011) conducted a clinical study with 142 patients predominantly diagnosed with follicular NHL to assess the efficacy of iodine-131 Rituximab radioimmunotherapy. All patients received the antibody with a radiation absorbed dose of $0.75 \mathrm{~Gy}$, and reached the following results: significant overall response rate in $68 \%$ of patients $(50 \%$ with complete response or unconfirmed complete response at 12 weeks); median overall survival of 87 months (range 1-131) and progression-free survival of 39 months (range 3-108). These results indicate a favorable response of patients to the iodine-131 rituximab radioimmunotherapy in routine clinical outpatient treatment of indolent NHL relapses, allowing half of the patients to achieve durable remission of symptoms.

Rituximab has also revolutionized treatment results of patients with aggressive lymphomas (including DLBCL) offering a higher chance of cure ( $76 \%$ in 5 years) (Belo, Sotomayor, 2007). Another study showed that patients with intermediate grade NHL and DLBCL were treated with R-CHOP. In this case, 33 patients diagnosed with relapsing diffuse lymphomas received 6 perfusions of $375 \mathrm{mg} / \mathrm{m}^{2}$ rituximab in the $1^{\text {st }}$ day of each cycle, combined with 6 doses of CHOP at the $3^{\text {rd }}$ day of each cycle. The overall response rate $94 \%, 20$ patients $(61 \%)$ presented complete response and 11 (33\%) exhibited partial response. These results were further confirmed in a Phase III randomized trial involving 400 elderly patients with aggressive lymphomas, where results revealed a significant improvement in the overall survival when the combined therapy was used as opposed to CHOP alone (83\% versus $68 \%$ ) (Bishop, 2012).

The GELA study (Groupe d'Etude des linfomas de l'Adulte) was the first Phase III clinical trial aimed at evaluating the effectiveness of R-CHOP in elderly patients $(n=399)$ with DLBCL. After two years, comparison of $\mathrm{R}-\mathrm{CHOP}$ and $\mathrm{CHOP}$ alone showed $57 \%$ versus $38 \%$ survival rates free of events, $70 \%$ versus $57 \%$ overall survival, and $52 \%$ versus $37 \%$ complete response, respectively, favoring the R-CHOP therapy (Coiffier, 2002). After 5 years, these rates remained significantly higher for the group with rituximab (Feugier et al., 2005).

Additionally, the influence of therapy on the occurrence of central nervous system (CNS) complications was investigated in 1,222 elderly patients (60-80 years) diagnosed with DLBCL and treated with $\mathrm{CHOP}$ with or without rituximab. It was found that $3.6 \%$ of the patients treated with R-CHOP $(n=608)$ had CNS complications, whereas the frequency of such complications increased to $5.9 \%$ patients treated with CHOP alone $(n=609)$. The estimated onset of CNS disease was 2 years, with a prevalence of $6.9 \%$ and $4.1 \%$ after $\mathrm{CHOP}$ and $\mathrm{R}-\mathrm{CHOP}$ therapies, respectively. In conclusion, the R-CHOP regimen reduced the risk of CNS disorders in elderly patients with DLBCL (Boehme et al., 2009).

Friedberg et al. (2011) conducted a multicenter phase II study using the combination of rituximab/ bendamustine/bortezomib in 31 patients, of which the majority (74\%) were men with a mean age of 64 years and with advanced stage disease (80\% stage III/IV) and asymptomatic at the beginning of the study. The cycle of treatment lasted 28 days. Bendamustine was infused at a dose of $90 \mathrm{mg} / \mathrm{m}^{2}$ on days 1 and 4 , rituximab at $375 \mathrm{mg} / \mathrm{m}^{2}$ on day 1 and bortezomib at $1.3 \mathrm{mg} / \mathrm{m}^{2}$ on days $1,4,8$ and 11. All together, 30 patients received $>1$ cycle of therapy, 25 patients $(81 \%)$ received $>4$ cycles of therapy, and 29 patients were evaluated for therapeutic response. The most common side effects were nausea $(50 \%)$, peripheral neuropathy (47\%), fatigue (47\%), constipation (40\%), fever $(40 \%)$, and diarrhea (27\%). As far as treatment, 9 
patients showed a partial response and in 15 of them a complete response was recorded. Among the 19 patients who received 6 cycles of the therapy, $18(95 \%)$ had a partial or a complete response to therapy. Despite the adverse effects, the study showed promising results for progression-free survival (PFS).

As seen, the reference treatment for DLBCL also indicates the use of R-CHOP, administered in 8 cycles at 21-day intervals. Another comparative study involving $\mathrm{R}-\mathrm{CHOP}$ versus CHOP for 7 years showed an increase in the overall survival (53 versus $36 \%$, respectively). It is noteworthy that 7 years is longer than the minimum period required to consider a patient cured ( 5 years). This was observed in patients older and younger than 60 (Hernández-Rivera et al., 2008).

The MInT (Mabthera International Trial) random trial investigated other chemotherapies combined with rituximab in patients aged between 18 and 60 and diagnosed with DLBCL. These patients received 6 cycles of conventional chemotherapies or chemotherapies associated with rituximab. After 34 months, the mean rates of event-free survival ( $79 \%$ versus $59 \%$ ), progression-free survival $(85 \%$ versus $66 \%)$ and overall survival $(93 \%$ versus $84 \%$ ) estimated for 3 years were higher in the rituximab group, with no increase in adverse events. As for the subgroup in stage II and with no bulky disease, the rate of survival, free of events, and the overall survival rate were $97 \%$ and $100 \%$, respectively, in 3 years. The worse results were seen in patients presenting bulky disease, where the rate of event-free survival was $76 \%$. Thus, the study's conclusion was that the 6-cycle R-CHOP administration may be considered as the standard treatment for young patients with high-grade lymphoma (Pfreundschuh et al., 2006).

A recent study by Stopeck et al. (2012) evaluated the possibility of combining bevacizumab, another MAb, with $\mathrm{CHOP}$ and $\mathrm{R}-\mathrm{CHOP}$ therapy to improve progression-free survival without adding toxicity in patients with recently diagnosed DLBCL and aged an average of 68 . It was observed that $62 \%$ of patients had severe hematological toxicity, 11 patients had febrile neutropenia and 14 (22\%) patients had gastrointestinal toxicity, including 5 cases of gastrointestinal perforation, 4 cases of thrombotic events and 11 developed mild ventricular dysfunction. Six patients older than 80 had severe toxicity $(100 \%)$ and therefore could not complete the 8 cycles of therapy defined in the protocol. Based on these results, the study concluded that there was no benefit to the combination of bevacizumab and CHOP to R-CHOP, given the evidence of significant toxicity, particularly cardiac and gastrointestinal perforation.
According to Coiffier (2002), the response to rituximab in B cell lymphomas remained for around 2 months, with detectable residual levels up to 6 months after the last infusion, indicating a long half-life of the antibody in circulation. During this period, normal B cell population declined and was recovered after 6 months, however, there were no opportunistic infections or an increase in infection rates since the amount of antibodies and $\mathrm{T}$ cells remained normal. Moreover, the HACA (human anti-chimeric antibody) response was not observed and myelosupression was rare.

The most common side effects, mainly after the first infusion ( $25 \%$ of cases), are fever, chills, rigors, rash, mild nausea, fatigue and malaise. These effects result from the rapid lysis of circulating $\mathrm{B}$ cells during the first infusion. In the second infusion, since the majority of circulating B cells have disappeared, the adverse effects are less pronounced (Belo, Sotomayor, 2007). Still, the typical adverse effects of Rituximab do not overcome the toxic effects of conventional chemotherapies, justifying again the use of these two resources (Czuczman, 2002). These responses, even if partial, are important since they are long-lasting and point to the advantages of the combined therapy over the use of rituximab alone (Bishop, 2012).

\section{Pharmacoeconomic analysis}

Due to the positive results obtained by rituximab treatment, this drug is currently considered the preferred treatment for NHL. Nevertheless, there are worries over its costs compared to conventional treatments, since it is obtained through biotechnology techniques (Czuczman et al., 2008). In addition, therapies for costly and long-lasting as this type of cancer, it is necessary to the national team for the treatment of illness, taking into account both the clinical effectiveness and cost-effectiveness of treatments available (Foster, 2009).

According to recent data, the cost for Mab Thera ${ }^{\circledR}$ is over $\mathrm{R} \$ 5,000$ for a vial of $500 \mathrm{mg}$ rituximab, and over $\mathrm{R} \$ 3,000$ for two vials of $100 \mathrm{mg}$ rituximab (Anvisa, 2013). Even information from the U.S. reports that the estimated cost per patient with follicular NHL is $\$ 36,000$ from diagnosis to the first year following treatment (Foster, 2009).

Based on these data, pharmacoeconomic analyses were performed with rituximab through studies of costutility and cost-effectiveness. Cost-utility analysis may be considered as a subtype of cost-effectiveness evaluation, where cost-efficacy considers the results in terms of clinical units, such as the cost per life year gained (LYG) and quality-adjusted life year (QALY). This is accepted as 
cost-benefit if the incremental ratio is lower than 50,000 in international currencies (Yoder, Kamal, 2009).

Based on these concepts, Groot et al. (2005) conducted a cost-utility study involving patients with DLBCL assuming direct medical costs (cost of medications and visit two specialists per year, on average). Younger patients (under 60 years) have been successful in getting QALY R-CHOP therapy over CHOP chemotherapy alone, which also represented a higher cost (more than 12.343 in total costs). Therefore, the incremental ratio for these patients was 13.983/QALY gains in the use of R-CHOP versus CHOP. A similar trend was observed with the older population, where the proportion was 17.933/QALY for incremental R-CHOP versus CHOP. Thus therapy with CHOP-R was found to be more cost-effective in terms of QALY gains while maintaining the accepted limit of 50,000 .

Ferrara and Revasio (2008) evaluated the costeffectiveness of R-CHOP versus CHOP in patients with good NHL prognosis, by analyzing responses in 3 scenarios: patients with a complete response in 5 months of survival; with relapse-free survival in 3 years; and with overall survival in 3 years. The costs included in this study were those that involved CHOP and rituximab, stem cell transplant, apheresis with hospitalization, and those related with hematology and biochemical, histological and imaging exams. The LYG per patient was 2.697 and 2.517 for R-CHOP and CHOP, respectively. The average total cost per patient was $\$ 22,113.44$ for R-CHOP and $\$ 22,831.17$ for CHOP. Thus, R-CHOP was more advantageous in regards to lower costs and better clinical results, being cost-effective when considering direct medical costs with good prospects in terms of LYG.

Another study evaluated the cost-effectiveness of maintenance treatment using the antibody in patients with refractory or relapsing follicular lymphoma that responded to R-CHOP or CHOP therapies. Through analysis of QALY, LYG variables and cost per year of life with no disease progression, the results indicated that rituximab was cost-effective in comparison to the standard treatment, since there was an increase in the progression of diseasefree survival leading to more years of life associated with a quality of life at an average cost of $\$ 9,358 /$ QALY (Capote et al., 2008).

With regard to the R-CVP versus CVP system, a pharmacoeconomic analysis in patients with previously untreated indolent NHL was conducted in Portugal. Considering a time horizon of 10 years, the total cost was lower per patient with CVP alone (€85.838) in comparison with R-CVP (€87.774), with, however, an increase in life expectancy and QALYs per patient with an R-CVP (6.361 and 4.166, respectively) regimen when compared to CVP (5.557 and 3.438, respectively), characterizing increases of 0.804 in LYG and 0.728 (8.7 months) in QALYs gained. The incremental cost per LYG was $€ 2,407$ and the incremental cost per QALY gained was $€ 2,661$. These results demonstrate that R-CVP therapy is a favorable alternative for indolent NHL patients, since it has shown positive clinical results, and cost-effectiveness (Braga et al. 2010).

Considering maintenance therapy with rituximab in follicular lymphoma, Deconinck et al. (2010) demonstrated the cost-effectiveness of therapy with respect to the number of LYGs and the total number of QALYs gained. 334 patients with a mean age of 54, with complete or partial remission, were selected to receive maintenance therapy with rituximab $(\mathrm{n}=167)\left(375 \mathrm{mg} / \mathrm{m}^{2}\right.$ intravenously, once every three months for a maximum 2 years) or to remain under observation without any additional treatment $(n=167)$. In the group that received rituximab it was observed that there was a significant elevation in mean PFS (51.5 months vs. 14.9 months, $\mathrm{p}$ $<0.001)$ and overall survival (OS) at 3 years $(85.1 \% v s$. $77.1 \%, \mathrm{p}=0.011)$. Maintenance therapy with rituximab, a significant increase in both average PFS in patients who responded to induction with $\mathrm{CHOP}$ (37.5 months vs. 11.6 months, $\mathrm{p}<0.0001$ ) and in those who received R-CHOP (51, for 9 months vs. 22.1 months, $\mathrm{p}=0.0071$ ) was observed. In addition, rituximab maintenance provided 1.19 years of additional survival time $(6.60$ years vs. 5,41$)$, an additional 1.04 QALY (4.72 years vs. 3.68 years), and 1.62 years most of PFS in the group of observation $(3.42$ years $v s .1 .80$ years). The total lifetime costs were $€ 71,314$ and $€ 62,251$ in the maintenance and observation groups, respectively. Therefore, maintenance with rituximab resulted in a gain of 1.19 years of survival or 1.04 QALYs at an additional cost of $€ 9,064$ compared to observation strategy. The relations of incremental cost-effectiveness were $€ 7,612$ per LYG and $€ 8,729$ per QALY. Finally, the results showed that the life expectancy and QALYs were increased by $22 \%$ and $28 \%$, respectively.

Recently, rituximab was evaluated as a maintenance therapy in first-line patients with follicular NHL, previously responsive to rituximab associated with cytotoxic chemotherapy (R-CTX). The survey conducted by Greenhalgh et al. (2013) is based on considerations of the manufacturer rituximab (Roche) and the evaluation of a group from the University of Liverpool, hired to act as an Evidence Review Group (ERG). The evidence from randomized Phase III with 1,018 patients took into account parameters such as PFS, overall survival (OS), response rates, adverse events (Aes) treatment and quality 
of life related to health (HR-QV). The manufacturer submitted an economic model (Markov) with the objective of demonstrating the possible benefits of maintenance therapy. This was accomplished in a period of two years to promote a projection of 25 years to capture the costs over the life and mean QALYs of a patient with follicular NHL, prospects of using the National Health Service (NHS, UK) and Social Service Personnel. The findings of this survey indicate that the data set is quite immature to draw definitive conclusions about the clinical and cost-effectiveness of the intervention. However, it was observed that the increase in PFS was observed in the primary benefit Markov model. At a third meeting, the Evaluation Committee concluded that rituximab could be recommended as the treatment of first-line maintenance for patients with follicular NHL whose disease has responded to induction with R-CTX.

\section{CONCLUSIONS}

A great advance for treating NHL patients was the introduction of rituximab MAb. Even though this drug has been used for over 10 years, its therapeutic potential is not totally clear. The mechanisms of cytotoxicity and induction of apoptosis, obtained in Phase II and III trials, indicate the need of further studies on the critical mechanisms of action involved in this treatment, which may maximize its therapeutic efficacy.

Results from clinical trials led rituximab Mab, initially approved by FDA for treating refractory or relapsing indolent NHL, to be included in the treatment for aggressive lymphomas. The association of this antibody to conventional chemotherapy agents such as CHOP and CVP has shown to be a viable option in treating almost all types of NHL. However, efforts continue to prospectively identify biological subsets of NHL needed to develop appropriate treatments.

The pharmacoeconomic studies cited in this review showed how economic analysis might influence decisionmaking on future clinical efforts. LYG and QALY applied in these studies are applicable and frequently used in cancer-related research. However, in order to validate the obtained results, the studies need to share a broad list of the implicated costs (drugs, lab exams, stem cell transplant, medical visits, and hospitalizations). In addition, there is also a need to analyze the therapy over time so that, finally, the decision is organized and based on the real clinical and economic impact that it offers, since it involves the allocation of health resources.

\section{REFERENCES}

AGÊNCIA NACIONAL DE VIGILÂNCIA SANITÁRIA. ANVISA. Regulação de mercado. Marcado de medicamentos. 2013. Available at: $<$ http://portal.anvisa.gov. $\mathrm{br} / \mathrm{wps} / \mathrm{portal} /$ anvisa/anvisa/posuso/regulacaodemercado $>$. Accessed on: 01 Aug. 2013.

ARAÚJO, L.H.L.; VICTORINO, A.P.O.S.; MELO, A.C.; ASSAD, D.X.; LIMA, D.S.; ALENCAR, D.R.; MOREIRA, M.M.L. Linfoma não-Hodgkin de alto grau - Revisão da literatura. Rev. Bras. Cancerologia, v.54, n.2, p.175-183, 2008.

BARR, P.M.; FU, P.; LAZARUS, H.M.; HORVATH, N.; GERSON, S.L.; KOC, O.N.; BAHLIS, N.J.; SNELL, M.R.; DOWLATI, A.; COOPER, B.W. Br. J. Haematol., v.147, n.1, p.89-96, 2009.

BELO, C.; SOTOMAYOR, E.M. Monoclonal antibodies for B cell lymphomas: rituximab and beyond. Hematology Am. Soc. Hematol. Educ. Program., p.233-242, 2007.

BISHOP, M.R. Monoclonal antibodies. 2012. Available at: $<$ http://www.meds.com/immunotherapy/monoclonal antibodies.html>. Accessed on: 08 May 2012

BYRD, J.C.; KITADA, S.; FLINN, I.W.; ARON, J.L.; PEARSON, M.; LUCAS, D.; REED, J.C. The mechanism of tumor cell clearance by rituximab in vivo in patients with B cell chronic lymphocytic leukemia: evidence of caspase activation and apoptosis induction. Blood, v.99, n.3, p.1038-1043, 2002.

BOEHME, V.; SCHMITZ, N.; ZEYNALOVA, S.; LOEFFLER, M.; PFREUNDSCHUH, M. CNS events in elderly patients with aggressive lymphoma treated with modern chemotherapy (CHOP-14) with or without rituximab: an analysis of patients treated in the RICOVER-60 trial of the German High-Grade Non-Hodgkin Lymphoma Study Group (DSHNHL). Blood, v.113, n.17, p.3896-3902, 2009.

BRAGA, P.; CARVALHO, S.; GOMES, M.; GUERRA, L.; LÚCIO, P.; MARQUES, H.; NEGREIRO, F.; PEREIRA, C.; SILVA, C.; TEIXEIRA, A. Análise económica de Rituximab. Em associação com Ciclofosfamida, Vincristina e Prednisolona no Tratamento de Doentes com Linfoma Folicular Avançado em Portugal. Acta Med. Port., v.23, p.1025-1034, 2010. 
CAPOTE, F.J.; CONDE, E.; FERNÁNDEZ, J.M.R.; GIRALDO, P.; GÓMEZ, J.C.; PROVENCIO, M.; RIOS, E.; RUEDA, A.; VARELA, C. Análisis farmacoeconómico de Rituximab en el tratamiento de mantemiento de los pacientes con linfoma folicular. Farm. Hosp., v.32, n.1, p.25-34, 2008.

CHANAN-KHAN, A. Bcl-2 antisense therapy in B cell malignancies. Blood Rev., v.19, n.4, p.213-221, 2005.

CHAO, M.K.; ALIZADEH, A.A.; TANG, C.; MYKLEBUST, J.H.; VARGHESE, B.; GILL, S.; JAN, M.; CHA, A.C.; CHAN, C.K.; TAN, B.T.; PARK, C.Y.; ZHAO, F.; KOHRT, H.E.; MALUMBRES, R.; BRIONES, J.; GASCOYNE, R.D.; LOSSOS, I.S.; LEVY, R.; WEISSMAN,I. L.; MAJETI, R. Anti-CD47 antibody synergizes with rituximab to promote phagocytosis and eradicate non-hodgkin lymphoma. Cell, v.142, n.5, p.699-713, 2010.

CHESON, B.D.; LEONARD, J.P. Monoclonal antibody therapy for B-cell non-Hodgkin's lymphoma. N. Engl. J. Med., v.359, n.6, p.613-626, 2008.

CLYNES, R.A.; TOWERS, T.L.; PRESTA, L.G.; RAVETCH, J.V. Inhibitory Fc receptors modulate in vivo cytoxicity against tumor targets. Nat. Med., v.6, n.4, p.443-446, 2000.

COIFFIER, B. The role of rituximab in lymphomas. Rev. Bras. Hematol. Hemoter, v.24, n.3, p.182-187, 2002.

CZUCZMAN, M.S. Immunochemotherapy in indolent nonhodgkin's lymphoma. Semin. Oncol., v.29, n.2, suppl.6, p.11-17, 2002.

CZUCZMAN, M.S.; OLEJNICZAK, S.; GOWDA, A.; KOTOWSKI, A.; BINDER, A.; KAUR, H.; KNIGHT, J.; STAROSTIK, P.; DEANS, J.; HERNANDEZILIZALITURRI, F.J. Acquirement of rituximab resistance in lymphoma cell lines is associated with both global CD20 gene and protein down-regulation regulated at the pretranscriptional and posttranscriptional levels. Clin. Cancer Res., v.14, n.5, p.1561-1670, 2008.

DECONINCK, E.; MIADI-FARGIER, H.; PEN, C.; BRICE, P. Cost effectiveness of rituximab maintenance therapy in follicular lymphoma long-term economic evaluation. Pharmacoeconomics, v.28, n.1, p.35-46, 2010.
FEUGIER, P.; VAN HOOF, A.; SEBBAN, C.; SOLALCELIGNY, P.; BOUABDALLAH, R.; FERMÉ, C.; CHRISTIAN, B.; LEPAGE, E.; TILLY, H.; MORSCHHOUSE, F.; GAULARD, H.; SALLES, G.; BOSLY, A.; GISSELBRECHT, C.; REYES, F.; COIFFIER, $\mathrm{B}$. Long-term results of the $\mathrm{R}-\mathrm{CHOP}$ in the treatment of elderly patients with diffuse large B cell lymphoma: a study by the Groupe d'Etude des Lymphomes de l'Adulte. J. Clin. Oncol., v.23, n.18, p.4117-4126, 2005.

FERRARA, F.; RAVASIO, R. Cost-effectiveness analysis of the addition of rituximab to $\mathrm{CHOP}$ in young patients with good-prognosis diffuse large-B cell lymphoma. Clin. Drug Investig., v.28, n.1, p.55-65, 2008.

FOSTER, T.; MILLER, J.D.; BOYE, M.E.; RUSSELL, M.W. Economic burden of follicular non-hodgkin's lymphoma. Pharmacoeconomics, v.27, n.8, p.657-679, 2009.

FRIEDBERG, J.W.; VOSE, J.M.; KELLY, J.L.; YOUNG, F.; BERNSTEIN, S.H.; PETERSON, D.; RICH, L.; BLUMEL, S.; PROIA, N.K.; LIESVELD, J.; FISHER, R.I.; ARMITAGE, J.O.; GRANT, S.; LEONARD, J.P. The combination of bendamustine, bortezomib, and rituximab for patients with relapsed/refractory indolent and mantle cell nonHodgkin lymphoma. Blood, v.117, n.10, p.2807-2812, 2011.

GREENHALGH, J.; BAGUST, A.; BOLAND, A.; BLUNDELL, M.; OYEE, J.; BEALE, S.; DUNDAR, Y.; HOCKENHULL, J.; PROUDLOVE, C.; CHU, P. Rituximab for the firstline maintenance treatment of follicular non-hodgkin's lymphoma. Pharmacoeconomics, v.31, n.5, p.403-413, 2013.

GROOT, M.T.; LUGTENBURG, P.J.; HORNBERGER, J.; HUIJGENS, P.C.; UYL-DE GROOT, C.A. Costeffectiveness of rituximab (MabThera) in diffuse large B-cell lymphoma in The Netherlands. Eur. J. Haematol., v.74, n.3, p.194-202, 2005.

HERNÁNDEZ-RIVERA, G.; AGUAYO-GONZÁLES, A.; CANO-CASTELLANOS, R.; LOARCA-PINÃ, L.M. Actualidades terapéuticas em el tratamiento de linfoma no hodgkin. Gac. Méd. Méx., v.144, n.3, p.275-277, 2008.

HORVÁTH, B.; DEMÉTER, J.; ERÕS, N.; HÁRSING, J.; CSOMOR, J.; MATOLCSY, A.; BOTTLIK, G.; GYÕRI, G.; MARSCHALKÓ, M.; KÁRPÁTI, S. Intravascular large B-cell lymphoma: remission after rituximab-cyclophosphamide, doxorubicin, vincristine and prednisolone chemotherapy. J. Am. Acad. Dermatol., v.61, n.5, p.885-888, 2009. 
IIDA, S.; KUNI-KAMOCHI, R.; MORI, K.; MISAKA, H.; INOUE, M.; OKAZAKI, A.; SHITARA, K.; SATOH, M. Two mechanisms of the enhanced antibody-dependent cellular cytotoxicity (ADCC) efficacy of non-fucosylated therapeutic antibodies in human blood. BMC Cancer, v.9, n.58, p.1-12, 2009.

\section{INSTITUTO NACIONAL DO CANCER. INCA. Non-hodgkin} lymphoma. Available at: http://www2.inca.gov.br/wps/ wcm/connect/tiposdecancer/site/home/linfoma_nao hodgkin >. Accessed on: 23 Apr. 2012.

INSTITUTO NACIONAL DO CANCER. INCA. Non-hodgkin lymphoma. Available at: http://www.inca.gov.br/conteudo view.asp?id=457. Accessed on: 23 Aug. 2013.

JAZIREHI, A.R.; BONAVIDA, B. Cellular and molecular signal transduction pathways modulated by rituximab (rituxan, anti-CD20mAb) in non-Hodgkin's lymphoma implications in chemosensitization and therapeutic intervention. Oncogene, v.24, n.13, p.2121-2143, 2005.

LEAHY, M.F.; TURNER, J.H. Radioimmunotherapy of relapsed indolent non-Hodgkin lymphoma with 131I-rituximab in routine clinical practice: 10-year single-institution experience of 142 consecutive patients. Blood, v.117, n.1, p.45-52, 2011.

KAHL, B.S.; BARTLETT, N.L.; LEONARD, J.P.; CHEN, L.; GANJOO, K.; WILLIAMS, M.E.; CZUCZMAN, M.S.; ROBINSON, K.S.; JOYCE, R.; VAN DER JAGT, R.H.; CHESON, B.D. Bendamustine is effective therapy in patients with rituximab-refractory, indolent B-cell nonhodgkin lymphoma. Cancer, v.116, n.1, p.106-114, 2010.

MARCUS, R. Use of rituximab in patients with follicular lymphoma. Clin. Oncol. (R. Coll. Radiol.), v.19, n.1, p.3849, 2007.

MARCUS, R.; IMRIE, K.; SOLAL-CELIGNY, P.; CATALANO, J.V.; DMOSZYNSKA, A.; RAPOSO, J.C.; OFFNER, F.C.; GOMEZ-CODINA, J.; BELCH, A.; CUNNINGHAM, D.; WASSNER-FRITSCH, E.; STEIN, G. Phase III study of R-CVP compared with cyclophosphamide, vincristine, and prednisone alone in patients with previously untreated advanced follicular lymphoma. J. Clin. Oncol., v.26, n.28, p.4579-4586, 2008

NATIONAL CANCER INSTITUTE. Non-hodgkin lymphoma. U.S.A., 2012. Available at: http://www.cancer.gov/ cancertopics/types/non-hodgkin. Acessed on: 02 June 2013.
OLIVEIRA, V.K.S.; COSTA, L.F.; FONSECA, A.C. Principais aplicações da biotecnologia na medicina. Rev. Eletr. Farm., v.3, suppl.2, p.42-43, 2006.

PFREUNDSCHUH, M.; TRUMPER, L.; OSTERBORG, A.; PETTENGELL, R.; TMENY, M.; IMRIE, K.; MA, D.; GILL, D.; WALEWSKI, J.; ZINZAANI, P.L.; STAHEL, R.; KVALOY, S.; SHPILBERG, O.; JAEGER, U.; HANSEN, M.; LEHTINEN, T.; LOPEZGUILlERMO, A.; CORRADO, C.; SCHELIGA, A.; MILPIED, N.; MENDILA, M.; RASHFORD, M.; KUHNT, E.; LOEFFLER, M. CHOP-like chemotherapy plus rituximab versus CHOP-like chemotherapy alone in young patients with good-prognosis diffuse large-B cell lymphoma: a randomized controlled trial by the MabThera International Trial (MinT) Group. Lancet Oncol., v.7, n.5, p.379-391, 2006.

PONTES, L.B.; KARNAKIS, T.; MALHEIROS, S.M.F.; WELTMAN, E.; BRANDT, R.A.; GUENDELMANN, R.A.K. Glioblastoma: enfoque no tratamento de pacientes idosos. Einstein, v.10, n.4, p.512-518, 2012.

STOPECK, A.T.; UNGER, J.M.; RIMSZA, L.M.; LEBLANC, M.; FARNSWORTH, B.; IANNONE, M.; GLENN, M.J.; FISHER, R.I.; MILLER, T.P. A phase 2 trial of standard-dose cyclophosphamide, doxorubicin, vincristine, prednisone (CHOP) and rituximab plus bevacizumab for patients with newly diagnosed diffuse large B-cell nonHodgkin lymphoma: SWOG 0515. Am. Soc. Hematol., v.120, n.6, p.1210-1217, 2012.

RAFIQ, K.; BERGTOLD, A.; CLYNES, R. Immune complexmediated antigen presentation induces tumor immunity. $J$. Clin. Invest., v.110, n.1, p.71-79, 2002.

RITTER, J.M.; LEWIS, L.D.; MANT, T.G.K.; FERRO, A. A textbook of clinical pharmacology and therapeutics. 5.ed. United Kingdom, 2008. 465 p.

SOCIEDADE BRASILEIRA DE CANCEROLOGIA. SBC. Linfomas. Available at: <http://www.sbcancer. org.br/home2/site/index.php?option=com_content\&vi ew=article \&id=120:linfomas \&catid=29:artigos-sobrecancer\&Itemid=123 >. Accessed on: 30 Aug. 2013.

SELENKO, N.; MAJDIC, O.; JAGER, U.; SILLABER, C.; STOCKL, J.; KNAPP, W. Cross-priming of cytotoxic T cells promoted by apoptosis-inducing tumor cell reactive antibodies? J. Clin. Immunol., v.22, n.3, p.124-130, 2002. 
SMITH, M.R. Rituximab (monoclonal anti-CD20 antibody): mechanisms of action and resistance. Oncogene, v.22, n.47, p.7359-7368, 2003.

STRAUSS, S.J.; MORSCHHAUSER, F.; RECH, J.; REPP, R.; SOLAL-CELIGNY, P.; ZINZANI, P.L.; ENGERT, A.; COIFfIER, B.; HOELZER, D.F.; WEGENER, W.A.; TEOH, N.K.W.; GOLDENBERG, D.M.; LISTE, T.A. Multicenter phase II trial of immunotherapy with the humanized anti-CD22 antibody, epratuzumab, in combination with rituximab, in refractory or recurrent non-Hodgkin's lymphoma. J. Clin. Oncol., v.20, n.24, p.3880-3886, 2006.

TAYLOR, R.P.; LINDORFER, M.A. Immunotherapeutic mechanisms of anti-CD20 monoclonal antibodies. Curr. Opin. Immunol., v.20, n.4, p.444-449, 2008.

TOBINAI, K.; ISHIZAWA, K.; OGURA, M.; ITOH, K.; MORISHIMA, Y.; ANDO, K. Phase II study of oral fludarabine in combination with rituximab for relapsed B cell non-Hodgkin's indolent. Cancer Sci, v.100, n.10, p.1951-1956, 2009.

UCHIDA, J.; HAMAGUCHI, Y.; OLIVER, J.A.; RAVETCH, J.V.; POE, J.C.; HAAS, K.M.; TEDDER, T.F. The innate mononuclear phagocyte network depletes B lymphocytes through Fc receptor-dependent mechanisms during antiCD20 antibody immunotherapy. J. Exp .Med., v.199, n.12, p.1659-1669, 2004.
VAN DER KOLK, L.E.; HAAS, M.; GRILLO-LÓPEZ, A.J.; BAARS, J.W.; OERS, M. H.J. Analysis of CD20-dependent cellular cytotoxicity by G-CSF-stimulated neutrophils. Leukemia, v.16, n.4, p.693-699, 2002.

VAN OERS, M.H.J.; KLASA, R.; MARCUS, R.E.; WOLF, M.; KIMBY, E.; GASCOYNE, R.D.; JACK, A.; VEER, M.V.; VRANOVSKY, A.; HOLTE, H.; GLABBEKE, M.; TEODOROVIC, I.; ROZEWICZ, C.; HAGENBEEK, A. Rituximab maintenance improves clinical outcome of relapsed/resistant follicular non-Hodgkin lymphoma in patients both with and without rituximab during induction results of a prospective randomized phase 3 intergroup trial. Blood, v.108, n.10, p.3295-3301, 2006.

VINJAMARAM, S.; HERNANDEZ-ILIZALITURRI, F.J.; RAJDEV, L.; SPARANO, J.A. Non-Hodgkin lymphoma. 2011. Available at: http://emedicine.medscape.com/ article/203399-overview. Accessed on: 10 July 2012.

VOSE, J.M. Personalized immunotherapy for the treatment of non-Hodgkin's lymphoma: a promising approach. Hematol. Oncol., v.24, n.2, p.47-55, 2006

YODER, J.L.; KAMAL, K.M. A systematic review of economic analyses studying rituximab in R-CHOP therapy in patients with non-Hodgkin lymphoma. The Open Cancer Immunol. J., v.2, p.1-9, 2009.

Received for publication on $16^{\text {th }}$ January 2013 Accepted for publication on $12^{\text {th }}$ February 2014 
